\title{
Evaluation of the Use of Two Teaching Techniques in Engineering
}

\author{
http://dx.doi.org/10.3991/ijep.v4i3.3287 \\ J. A. Álvarez, J. Segundo, C. Álvarez, J.C. Arellano, and A. A. Pérez \\ Universidad Autónoma de San Luis Potosí, San Luis Potosí, México.
}

\begin{abstract}
This paper presents an analysis of the practical implementation of two teaching techniques so-called Problem-Based Learning and Cooperative Learning. These techniques were applied to some courses in the Department of Mechanical and Electrical Engineering and evaluated through assessment rubrics.
\end{abstract}

In a sample of students and teachers, the assessment rubrics were applied to numerically evaluate the proportion of each course, in which the teacher uses traditional teaching versus teaching for meaningful learning. The results of the presented analysis allow to verify the use of these teaching techniques by professors of the Department of Mechanical and Electrical Engineering.

This activity was developed as a part of the work established by the Institutional Development Plan of the Faculty of Engineering, which includes the strategic objective of developing an innovative educational model in the following ten years.

Index Terms-Cooperative learning, meaningful learning, problem-based learning.

\section{INTRODUCTION}

It is an absolute necessity that the academic staff of higher education institutions (HEIS) are updated permanently, both in discipline and in pedagogy, in order to encourage students towards a comprehensive training for the professional life enable them to deal with challenges thereof. According to this, in 2011 the Academic Secretary of the Faculty of Engineering (FE) of the Universidad Autonoma de San Luis Potosí (UASLP), proposed the participation of the academic staff in the course workshop of meaningful learning in which two teaching techniques were analyzed: problem-based learning (PBL) and cooperative learning (CL). This activity would promote the educational upgrading of teachers with different seniority and education levels.

The PBL is one of the most popular teaching techniques in higher education institutions on the last years. This approach inverts the traditional teaching since the PBL presents the problem firstly, then students identify the learning needs and look for information, finally return to the original problem to solve it. PBL promotes the connection between different fields of study. On other hand, the traditional teaching exposes the basics firstly and then looks for problems for practical application of basics [1].

Throughout the process, from the problem statement to the solution, students work together in small groups, promoting in this learning experience to practice and develop skills in observation and reflection regarding with atti- tudes and values that can not easily achieved by traditional teaching approach.

In regards to the CL approach, the main idea is to learn or attempt to learn something together. In the classroom, students are divided into groups after the teacher explains in detail the specific problem. Within each group, students share information and work together to ensure that each student in the group understands and completes the assigned activity. This approach turns the class in an open forum for communication between all participants, i.e. students and teachers. Moreover, passive students are encouraged to actively participate in interesting and challenging situations [2].

Comparative results obtained from PBL and CL against the traditional learning method reveal that students learn more, remember more for more time, develop higher critical thinking and thinking skills, and feel more confident and accepted for themselves and for the others [3], [4], [5], [6], [11].

With reference to the above mentioned, a group of teachers that collaborate with the Academic Secretary in monitoring the Institutional Development Plan (IDP), carried out an analysis in 2012 on the practical implementation of PBL and CL by the teachers who took the course workshop of meaningful learning. The Department of Mechanical and Electrical Engineering (DME) was selected to apply a rubric teacher-student at the end of the semester following the semester in which the course workshop was given.

\section{BACKGROUND}

In the last century there was not an explicit concern of teachers for find out if teaching methods were able to develop skills in students. Teachers were typically owners of knowledge; their purpose was to transmit information to students and, in the best case, they tried to contribute for students to learn. Generally the teaching competencies were focused on passive education [7], [8], [9], [10].

In Figure 1 is shown a closed-loop in which the teacher must engage, beginning with a reflection about his teaching, goes through a process of training and educational upgrading, develops educational projects and task allowing him to diversify his teaching, incorporates new technological tools, implements his strategies in the classroom, collects students' experiences and think about his teaching again.

On the other hand, the implementation of a pedagogical and disciplinary training program presents challenging issues for HEIS, e.g., economical and infrastructure needs as well as unwillingness to new technologies. However, this training also represents the opportunity for teachers to 
PAPER

Evaluation of The Use of Two TEACHING TECHNIQUES IN ENGINEERING

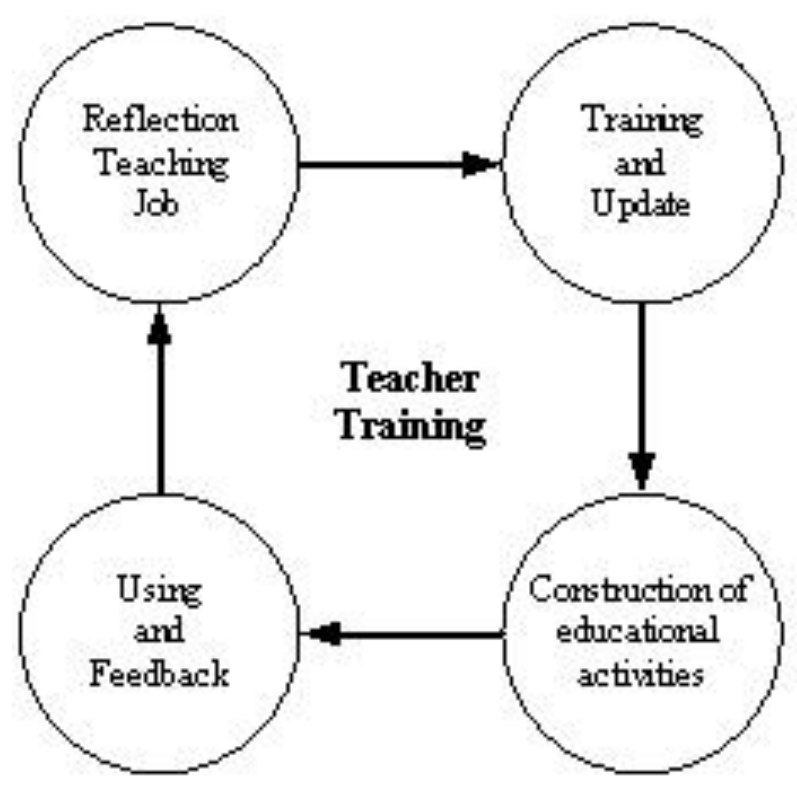

Figure 1. Teacher-training process.

promote their teaching competencies and to stimulate educational innovation in classroom. The UASLP and specifically the FE has taken initiatives on this way.

The Department of Mechanical and Electrical Engineering is one of the largest academic departments of the FE, and constantly updates its educational programs and its academic staff. The DME has the following programs:

- Electromechanical Engineering

- Mechanical Industrial Management Engineering

- Mechanical Engineering

- Electrical Engineering

- Mechatronic Engineering

The five educational programs share several courses both in the electrical area as in the mechanical. There are around 1600 students and 270 courses each semester.

An important aspect to consider in the DME is the academic staff since it is in a generational transition due to the high rate of retirement that started 10 years ago. Consequently, hiring of teachers has been increasing and because of this the average seniority is lesser than 15 years

This generational transition has implied especial efforts towards pedagogical and disciplinary training of the new academic staff in order to engage them in teaching competencies to meet the academic needs of DME.

In the following sections is described the planning and monitoring of the methodology proposed and reported as part of the Institutional Development Plan.

\section{METHODOLOGY}

In 2011, the Academic Secretary of the Faculty of Engineering proposed a didactic training program for teachers that were serving as presidents and secretaries of academic boards as well as the academic staff involved in curriculum committees. In order to achieve this goal, experts in competency-based learning were hired to give a course workshop of didactic techniques with the purpose of teach teachers to use CL and PBL techniques.

\section{A. Training}

Forty teachers of DME representing twenty academic boards including mechanical, electrical and administrative departments were enrolled in the course workshop. In addition, 105 teachers of the FE, including DME, with different levels of seniority and areas of study were enrolled in the training process.

The requirement for each teacher for pass the course workshop was to attend at least $90 \%$ of the sessions and develop and implement an activity with their students using PBL and CL. This process should engage teachers into a reflexive process in order to implement new teaching techniques in their courses and thus promote meaningful learning.

\section{B. Implementation}

During two semesters in 2012, teachers of DME would implement the teaching methods covered in the course workshop of meaningful learning. Some of these teachers are involved in the following courses:

1. Manufacturing Processes

2. Kinematics of Machines

3. Materials Engineering

4. Mechanics of Materials

5. Electromagnetics

6. Electrical Circuits

7. Operations Research

8. Electronics

9. Numerical Analysis

10. Fluid Mechanics

11. Power Systems

12. Programming

13. Digital Electronics

14. Thermodynamics

\section{Control Systems}

For teachers, this experience meant an invaluable opportunity to complement the teaching-learning process. However, for some teachers, the transition from the traditional method to new teaching methods is difficult, particularly for teachers that had been teaching the same courses for a long time. In these cases, the transition could be softer if the teachers combine the traditional and new teaching methods as an intermediate stage and eventually they completely move to the new teaching methods based on meaningful learning.

Figure 2 shows the average relation in percent between the courses given each semester and the seniority of the teachers giving those courses at the time when the survey was applied.

The UASLP and the FE promote academic freedom and consequently teachers are not forced to implement new teaching methods. Therefore, the transition from one teaching technique to other should be a dynamic process and requires a teacher commitment to balance and evaluate objectively the performance of the traditional and new teaching methods in the classroom as is shown in Figure 1. 


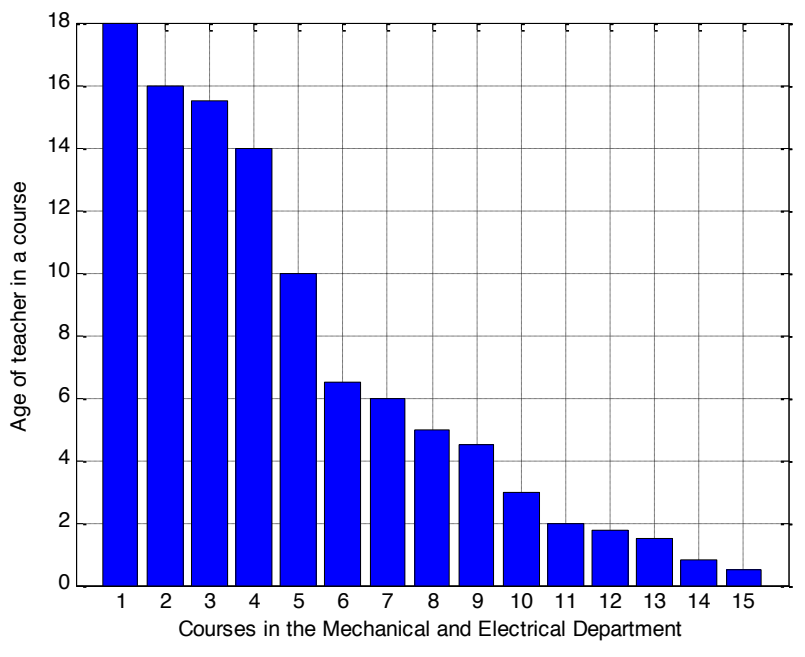

Figure 2. Age of teacher in a course

\section{Evaluation}

A survey was applied to a selected group of teachers and students for measuring the impact of the course workshop of meaningful learning on practical applications in the classroom. The evaluation was carried out through a rubric that measured numerically traditional teaching and teaching methods based on meaningful learning. However, the survey was not limited to determinate if ABP and CL were the only teaching methods used by teachers. The first question of the survey was about any teaching methods used by teacher and then proceeded to evaluate the criteria of the meaningful teaching.

The survey was applied in 2012 at the end of the two semesters. The selected group of teachers and students was chosen at random taking into account the forty teachers of DME that participated in the course workshop. 85\% of responders reported that they had used only new teaching techniques or in a combination with the traditional method. The remaining $15 \%$ said to be using traditional teaching. It should be mentioned, that some teachers wished the survey be conducted at the end of the second semester of 2012 and not in the first semester, as they sought to expand the resources learned in the course workshop.

Table I lists the scores that were applied to the five criteria that evaluate meaningful learning methodology. These criteria were used for students and teachers. The best evaluation accumulates 20 points and the worst 5 points.

Table II shows the descriptions of the criteria used to evaluate students and teachers. We sought to evaluate the methodology through the integration of students in meaningful learning.

For students it is important to have an activity in PBL/CL, where the methodology proposed by the teacher allows them to function both independently and in groups to solve the given problem [12], [14].

Moreover, the teacher must structure in a clear and objective way the educational tools so these can contribute to meaningful learning of the course in order to engage efficiently students and therefore they find interesting to work in groups and experiment new learning scenarios.
TABLE I.

SCORES FOR CRITERION

\begin{tabular}{|l|c|c|c|c|}
\hline \multirow{2}{*}{ Criteria } & \multicolumn{5}{|c|}{ Level of achievement } \\
\cline { 2 - 5 } & Very good (4) & Good (3) & Regular (2) & $\begin{array}{c}\text { Not yet suffi- } \\
\text { cient (1) }\end{array}$ \\
\hline Criterion 1 & - & - & - & - \\
\hline Criterion 2 & - & - & - & - \\
\hline Criterion 3 & - & - & - & - \\
\hline Criterion 4 & - & - & - & - \\
\hline Criterion 5 & - & - & - & - \\
\hline
\end{tabular}

TABLE II.

CRITERIONS OF STUDENTS AND TEACHERS

\begin{tabular}{|c|l|l|}
\hline Criterion & \multicolumn{1}{|c|}{ Student } & \multicolumn{1}{c|}{ Teacher } \\
\hline 1 & Methodology development & $\begin{array}{l}\text { Description of methodolo- } \\
\text { gy }\end{array}$ \\
\hline 2 & Quality of didactic resources & Group communication \\
\hline 3 & Teacher involvement & Group involvement \\
\hline 4 & Empathy between students & Perspectives of students \\
\hline 5 & Self-knowledge & $\begin{array}{l}\text { Construction of } \\
\text { knowledge }\end{array}$ \\
\hline
\end{tabular}

In the next stage it is presented the results obtained from the survey applied to teachers of DME. This activity was conducted in two periods during 2012. While the survey was applied to the teacher of the group, a student that was chosen randomly answered the same survey.

\section{Statistical RESUlts}

The survey showed that teachers used the techniques learned in the course workshop. However, this represented only $44 \%$ of the courses of DME, while the traditional method was still the most used teaching method since it represented $56 \%$ (Figure 3 ).

The obtained results were better than expected, considering that it was an extra activity to the teaching and research activities. It is important to remark that some teachers had been teaching without new teaching resources or new didactic tools and others teachers were new in the DME or in the courses.

As per Figure 3, PBL and CL represent a $44 \%$ of the teaching methods used in the DME. From this $44 \%$, PBL and CL represent $37 \%$ and $63 \%$, respectively, as shown in Figure 4; since CL is easy to implement, this is more used than PBL [13], [14].

The average assessment by criteria (Table 2) associated with the rubrics of teachers and students are shown in Figures 5 and 6, respectively. Note that the numerical evaluation of criteria 1,3 and 5 is similar between the rubrics of students and teachers. According to this similarity, the following observations are done:

Criterion 1: Students find easier to implement the methodology if it is clearly described.

Criterion 3: An integrated group involves the teacher (as a guide) as well as the performance and commitment of the students (collaborative work).

Criterion 5: The teacher, in order to the students to recognize the acquisition of meaningful learning should monitor the construction of knowledge and student performance. 


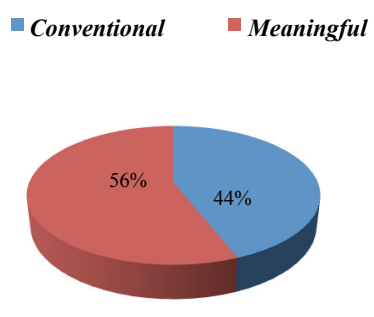

Figure 3. Teaching methods in the classroom: teaching methods based on meaningful learning versus traditional teaching.

\section{$\square P B L \quad \square$ Coperative learning}

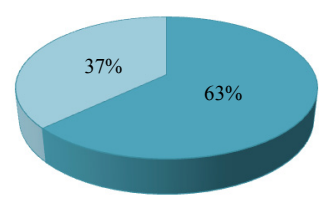

Figure 4. Meaningful learning methods: PBL versus CL.

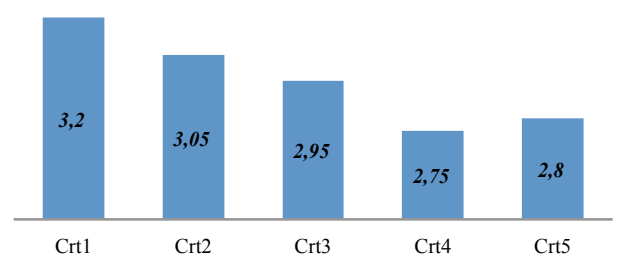

Figure 5. Average assessment by criteria of the teacher rubric

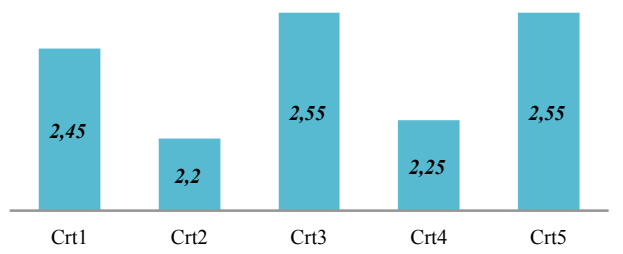

Figure 6. Average assessment by criteria of the student rubric.

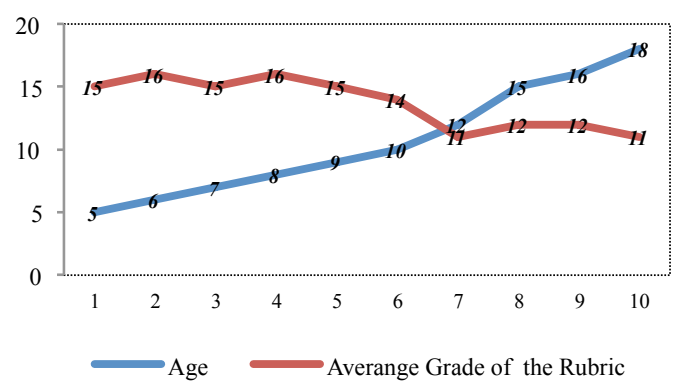

Figure 7. Age of the teachers vs. grade of the rubric.

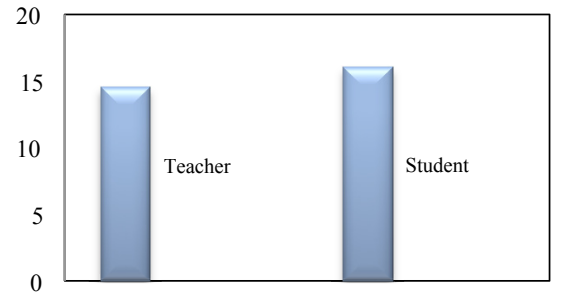

Figure 8. Average assessment of the rubrics of teachers and students.

When a course has been given for many semesters means it is necessary to update teaching methods, but sometimes there is resistance to change. In Figure 7, we present a sample of 10 courses of DME that were surveyed, which show the relation of the seniority per course and the average assessment of the used rubrics.

It is observed that the higher numerical evaluation of rubrics are given in courses with less than 10 years of being given by the same teacher. It is considered that at this time the teacher has acquired a good knowledge of the course; however, it has not identified a specific teaching method in the classroom.

Figure 8 shows the comparison between the average assessment of the teacher rubric and students. It is important to remark that teachers and student answered the survey independently of each other. Therefore, the proximity of these two average evaluations is a good indicator to measure whether the techniques are applied and combined with traditional teaching and if these are also assimilated by students.

\section{CONCLUSIONS}

In the teacher's role as an agent of change and guidance in finding the best teaching technique for students in the classroom, he must always favor the formation of leaders in their own area of knowledge in order to create social wealth.

The teaching techniques as PBL and CL promote better assimilation of knowledge in students. However, it is considered that traditional teaching techniques in engineering should not be totally replaced by these new teaching methods; it is the combination, which strengthens the teaching-learning process.

In accordance with experience of surveyed teachers, teaching techniques work but are new for students and this forces the teacher to give them greater induction in order to follow these teaching methods in the classroom. It is considered that the continuous training and monitoring through course workshops will eventually change teaching techniques.

The reported evaluation gave invaluable information that will allow to take decisions towards the practical implementation of an innovative educational model in accordance with the current needs in the university.

\section{ACKNOWLEDGMENT}

The authors thank the Universidad Autónoma de San Luis Potosí (UASLP) through the Facultad de Ingeniería, students and teachers for the facilities that were granted to carry out this investigation. 


\section{REFERENCES}

[1] E. D. Graaff and A. Kolmos, Management of Change: implementation of Problem Based and Project Based Learning in Engineering. Sense Publishers, 2006.

[2] K. A. Smith, "Cooperative learning: effective teamwork for engineering classrooms," in Frontiers in Education Conference, 1995. Proceedings., 1995, 1995, vol. 1, pp. 2b5.13-2b5.18 vol.1.

[3] C. Zhou, A. Kolmos, and J. F. D. Nielsen, "A Problem and Project-Based Learning (PBL) Approach to Motivate Group Creativity in Engineering Education," Int. J. Eng. Educ., vol. 28, no. 1, pp. 3-16, 2012.

[4] J. Biggs, "Enhancing teaching through constructive alignment," High. Educ., vol. 32, no. 3, pp. 347-364, Oct. 1996. http://dx.doi.org/10.1007/BF00138871

[5] C.-H. Lai, B.-S. Jong, Y.-T. Hsia, P. F. Lee, and T.-Y. Chan, "Systematic analysis of peer interaction in cooperative learning," in Frontiers in Education Conference (FIE), 2011, 2011, pp. S4E1-S4E-7.

[6] A. L. Kern, T. J. Moore, and F. C. Akillioglu, "Cooperative learning: Developing an observation instrument for student interactions," in Frontiers In Education Conference - Global Engineering: Knowledge Without Borders, Opportunities Without Passports, 2007. FIE '07. 37th Annual, 2007, pp. T1D-1-T1D-6.

[7] A. Rugarcia, R. M. Felder, D. R. Woods, and J. E. Stice, "The future of engineering education I. A vision for a new century," Chem. Eng. Educ., vol. 34, no. 1, pp. 16-25, 2000.

[8] D. R. Woods, R. M. Felder, A. Rugarcia, and J. E. Stice, "The future of engineering education III. Developing critical skills," change, vol. 4, pp. 48-52, 2000.

[9] K. Khalaf, S. Balawi, G. W. Hitt, and M. A. M. Siddiqi, "Engineering Design Education: Effect of Mode of Delivery," Int. J. Eng. Pedagogy Ijep, vol. 3, no. S2, pp. pp. 46-53, Feb. 2013.

[10] K Khalaf, G.W. Hitt, S. Balawi and M.M. Siddiqi, "Enginnering Design Education: Effect of Mode Delivery", IGIP2012 Conference, Vol 3, No. 2, pp 46-53, 2013. http://dx.doi.org/10.3991/ ijep.v3iS2.2447

[11] K. Mohd-Yusof, S.A.H.S. Hasan, M.Z. Jamaludin, N.F. Harun, "Cooperative Problem-Base Learning (CPBL): A practical PBL model for engineering courses", IEEE Global Engineering Education Conference (EDUCON), 2011, pp 366373http://dx.doi.org/10.1109/EDUCON.2011.5773162
[12] Johnson, D. W.; and Johnson, R.T., "Making Cooperative Learning Work," Theory into Practice, Vol. 38, No. 2, Building Community through Cooperative Learning. (Spring, 1999).

[13] M. A. Albanese and S. Mitchell, "Problem-based learning: a review of the literature on outcomes and implementation issues", Acad. Med.,vol. 68, no. 1, pp.52-8, 1993. http://dx.doi.org/ 10.1097/00001888-199301000-00012

[14] J.A. Álvarez, J.C. Arellano, J. Segundo, L. Galván y A.A Pérez., "Reporte Interno del PIDE 2010-2013: Desarrollo de un Modelo Educativo Innovador", Facultad de Ingeniería, UASLP 2012.

\section{AUTHORS}

J. A. Álvarez is with of the Faculty of Engineering of the Universidad Autónoma de San Luis Potosí, México (email: jaas@uaslp.mx)

J. Segundo is with of the Faculty of Engineering of the Universidad Autónoma de San Luis Potosí, México (email: juan.segundo@uaslp.mx)

C. Álvarez is with of the Faculty of Engineering of the Universidad Autónoma de San Luis Potosí, México (email: claudia.salas@uaslp.mx)

J. C. Arellano is with of the Faculty of Engineering of the Universidad Autónoma de San Luis Potosí, México (email: carlos.arellano@uaslp.mx)

A. A. Pérez is with of the Faculty of Engineering of the Universidad Autónoma de San Luis Potosí, México (email: aaperez@uaslp.mx)

Submitted 25 October 2013. Published as re-submitted by the authors 13 June 2014.

\section{APPENDIX}

This section (see next page) includes the full version of assessments and rubrics used in the surveys of students and teachers. 


\section{UNIVERSIDAD AUTÓNOMA DE SAN LUIS POTOSÍ \\ FACULTAD DE INGENIERÍA IDP 2010-2023 \\ Strategy 3.1 Permanent updating of the curriculum \\ STUDENT EVALUATION \\ USE OF PBL AND/OR CL BY TEACHING JOB}

Course name: Group:

Select the teaching method used in this course along the semester:

a) Traditional: Lectures and direct instructions ( )

b) Meaningful learning: Problem-Based Learning PBL ( ) and/or Cooperative Learning ( )

c) Traditional and Meaningful Learning ( )

d) Other (indicate the used teaching method)

If the teacher used a teaching method based on meaningful learning perform the following evaluation:

\begin{tabular}{|c|c|}
\hline Criterion & Score \\
\hline 1 & \\
\hline 2 & \\
\hline 3 & \\
\hline 4 & \\
\hline 5 & \\
\hline Total & \\
\hline
\end{tabular}

\section{STUDENT RUBRIC}

\begin{tabular}{|c|c|c|c|c|c|}
\hline \multicolumn{2}{|r|}{ CRITERION } & VERY GOOD (4) & GOOD (3) & SUFFICIENT (2) & INSUFFICIENT (1) \\
\hline & $\begin{array}{l}\text { Methodology de- } \\
\text { velopment }\end{array}$ & $\begin{array}{c}\text { The teacher describes completely } \\
\text { and well supported the used work } \\
\text { method and its advantages. }\end{array}$ & \begin{tabular}{|c|} 
The teacher describes in \\
detail the work method and \\
some of its advantages.
\end{tabular} & $\begin{array}{l}\text { The teacher describes in } \\
\text { detail the work method }\end{array}$ & $\begin{array}{c}\text { The teacher describes poorly } \\
\text { the work method. }\end{array}$ \\
\hline 2. & $\begin{array}{l}\text { Quality of didactic } \\
\text { resources }\end{array}$ & $\begin{array}{l}\text { The didactic resources presented by } \\
\text { the teacher are well written, with } \\
\text { inventive and creativity, including } \\
\text { clear and precise instructions. }\end{array}$ & $\begin{array}{l}\text { The didactic resources } \\
\text { presented by the teacher } \\
\text { are well written and in- } \\
\text { clude clear and precise } \\
\text { instructions. }\end{array}$ & $\begin{array}{l}\text { The didactic resources } \\
\text { presented by the teacher } \\
\text { are well written. }\end{array}$ & $\begin{array}{l}\text { The didactic resources } \\
\text { presented by the teacher are } \\
\text { unclear and he is poorly } \\
\text { detailed in the instructions. }\end{array}$ \\
\hline 3. & $\begin{array}{l}\text { Teacher involve- } \\
\text { ment }\end{array}$ & $\begin{array}{l}\text { The teacher monitors the work } \\
\text { performed by the students and } \\
\text { encourages students participation } \\
\text { during the activity. }\end{array}$ & $\begin{array}{l}\text { The teacher monitors the } \\
\text { work performed by stu- } \\
\text { dents. }\end{array}$ & $\begin{array}{l}\text { The teacher observes the } \\
\text { work performed by stu- } \\
\text { dents. }\end{array}$ & $\begin{array}{c}\text { The teacher does not interact } \\
\text { with students during the } \\
\text { activity. }\end{array}$ \\
\hline 4. & $\begin{array}{l}\text { Empathy between } \\
\text { students }\end{array}$ & $\begin{array}{c}\text { The activity allows to see and feel } \\
\text { what others see and feel. There is } \\
\text { openness to seek what is strange, } \\
\text { unknown or different. }\end{array}$ & $\begin{array}{c}\text { They are willing to see and } \\
\text { feel what others see and } \\
\text { feel. There is openness to } \\
\text { seek what is unknown. }\end{array}$ & $\begin{array}{l}\text { It is known that the others } \\
\text { see and feel different. It is } \\
\text { difficult to understand the } \\
\text { strange or unknown. }\end{array}$ & There is not empathy. \\
\hline 5. & Self-knowledge & $\begin{array}{c}\text { The work method allows to have a } \\
\text { deep awareness of the boundary } \\
\text { between our self-understanding and } \\
\text { the understanding of others. Exist } \\
\text { the ability to recognize prejudice. }\end{array}$ & $\begin{array}{c}\text { There is awareness of own } \\
\text { and others' ignorance. It is } \\
\text { known the strengths and } \\
\text { limitations of the under- } \\
\text { standing itself. }\end{array}$ & $\begin{array}{l}\text { There is an awareness of } \\
\text { what is understood and } \\
\text { what is not understood. }\end{array}$ & $\begin{array}{c}\text { There is no awareness of } \\
\text { individual limitations or own } \\
\text { ignorance. }\end{array}$ \\
\hline
\end{tabular}




\section{UNIVERSIDAD AUTÓNOMA DE SAN LUIS POTOSÍ FACULTAD DE INGENIERÍA IDP 2010-2023 \\ Strategy 3.1 Permanent updating of the curriculum TEACHER EVALUATION \\ USE OF PBL AND/OR CL BY TEACHING JOB}

Course name: Group:

Select the teaching method used in this course along the semester:

a) Traditional: Lectures and direct instructions ( )

b) Meaningful learning: Problem-Based Learning PBL( ) and/or Cooperative Learning ( )

c) Traditional and Meaningful Learning ( ): \%Traditional

d) Other (Indicate the used teaching method) $\%$ PBL $\% \mathrm{CL}$

If you used a teaching method based on meaningful learning perform the following evaluation:

\begin{tabular}{|c|c|}
\hline Criterion & Score \\
\hline 1 & \\
\hline 2 & \\
\hline 3 & \\
\hline 4 & \\
\hline 5 & \\
\hline Total & \\
\hline
\end{tabular}

TEACHER RUBRIC

\begin{tabular}{|c|c|c|c|c|}
\hline CRITERIO & VERY GOOD (4) & GOOD (3) & SUFFICIENT (2) & INSUFFICIENT (1) \\
\hline $\begin{array}{l}\text { 1. Description of } \\
\text { methodology }\end{array}$ & $\begin{array}{l}\text { It is understood fully and well } \\
\text { supported the work methodolo- } \\
\text { gy and the advantages of it. It } \\
\text { captures the interest of the } \\
\text { whole group. }\end{array}$ & $\begin{array}{l}\text { It is understood in detail the } \\
\text { methodology and mentioned } \\
\text { the advantages of using this } \\
\text { methodology. }\end{array}$ & $\begin{array}{l}\text { It is understood in detail the } \\
\text { methodology. }\end{array}$ & Methodology is not clear. \\
\hline $\begin{array}{l}\text { 2. Group communi- } \\
\text { cation }\end{array}$ & $\begin{array}{c}\text { Students converse and reach } \\
\text { agreements effectively. Disa- } \\
\text { greements are solved construc- } \\
\text { tively. }\end{array}$ & $\begin{array}{c}\text { Students discuss and dialogue } \\
\text { to approach their points of } \\
\text { view. }\end{array}$ & $\begin{array}{c}\text { Some students discuss and } \\
\text { defend their points of view. } \\
\text { Disagreements are solved } \\
\text { pacifically. }\end{array}$ & $\begin{array}{l}\text { It is not understood the } \\
\text { contributions of others. }\end{array}$ \\
\hline 3. Group involvement & $\begin{array}{l}\text { There is a balance in the distri- } \\
\text { bution of responsibilities and } \\
\text { the final products are produced } \\
\text { by all participants }\end{array}$ & $\begin{array}{c}\text { Students work together and } \\
\text { each meets the corresponding } \\
\text { role to obtain the final prod- } \\
\text { ucts. }\end{array}$ & $\begin{array}{l}\text { The products obtained from } \\
\text { the activity were developed } \\
\text { by a single student but re- } \\
\text { ceived help from the other } \\
\text { students. }\end{array}$ & $\begin{array}{l}\text { One student developed the } \\
\text { products obtained from the } \\
\text { activity. }\end{array}$ \\
\hline $\begin{array}{l}\text { 4. Perspectives of } \\
\text { students }\end{array}$ & $\begin{array}{l}\text { It is considered new points of } \\
\text { view critics and dispassionate. } \\
\text { Comparisons are made rein- } \\
\text { forcing the own perspective by } \\
\text { contrast with the others. }\end{array}$ & $\begin{array}{l}\text { It is considered points of } \\
\text { view critics and insightful. } \\
\text { Includes perspectives of } \\
\text { others. }\end{array}$ & $\begin{array}{c}\text { There are different points of } \\
\text { view. It can be presented a } \\
\text { point of view and criticism } \\
\text { itself is weak. }\end{array}$ & $\begin{array}{l}\text { No one is aware of the } \\
\text { diversity of views and } \\
\text { arguments are subjective. }\end{array}$ \\
\hline $\begin{array}{l}\text { 5. } \begin{array}{l}\text { Construction of } \\
\text { knowledge }\end{array} \\
\text { knowlon }\end{array}$ & $\begin{array}{l}\text { The student proves to have the } \\
\text { ability to use knowledge effec- } \\
\text { tively and adjust the under- } \\
\text { standing in new contexts. }\end{array}$ & $\begin{array}{c}\text { The student proves to have } \\
\text { the ability to use knowledge } \\
\text { and adjust the understanding } \\
\text { in different contexts. }\end{array}$ & $\begin{array}{l}\text { The student performs well in } \\
\text { simple contexts }\end{array}$ & $\begin{array}{c}\text { The student performs well } \\
\text { only with guidance }\end{array}$ \\
\hline
\end{tabular}

